\title{
PUBLIC DIPLOMACY OF THE UNITED STATES OF AMERICA IN AFGHANISTAN
}

\author{
Monika Kornacka
}

Akademia Humanistyczna w Pułtusku

\begin{abstract}
The United States failed to prevent the terrorist attacks of September 11 $1^{\text {th }}$ despite its superpower status and great potential. The severe response to the attacks - interventions in Afghanistan and Iraq - did not provide a sense of security to the Americans. Moreover, these actions resulted in the loss of popularity and credibility of the United States throughout the world, especially within Muslim populations. This article provides background on the U.S. public diplomacy efforts in Afghanistan, presents a brief overview of tools used to win "hearts and minds" of Afghans as well as recommendations and conclusions concerning the conduct of public diplomacy in Afghanistan beyond 2014.
\end{abstract}

Keywords: public diplomacy, Aghanistan, Iraq, conflict, conflict resolution, security policy

\section{Introduction}

The terrorist attacks of September 11 $11^{\text {th }}, 2001$ shocked the whole world. In an atmosphere of grief, fear and uncertainty, people frequently asked two questions - who did this and why. The answer to the second question proved to be more difficult and to this day is not clear. Nevertheless, for many observers of public life it was obvious that one of the main reasons behind the attacks was situation in the Muslim world - weak governance, tribalism, poverty, insecurity, corruption, the drug trade, high unemployment - these factors offer a fertile breeding ground for violent radicalism and reinforce the anti-American sentiments, which facilitate the recruitment of new members of radical groups.

It is essential to understand that ensuring national security is no longer merely a matter of defending borders and patrolling oceans and skies, but requires reconstruction and stabilization efforts, building partnerships, and improving the U.S. image abroad ${ }^{1}$. The strategy towards Afghanistan is also based on such logic - only stable Afghanistan with a strong government and high growth rate, which public sees the advantages of cooperation with the United States, will not pose a threat to the security of the United States. But as the U.S. have set end date for its active military engagement, Afghanistan is once again threatened with disorder and insecurity. The political and economic reconstruction process is in danger of stalling. The Afghan people are confused and uncertain about the future. It is legitimate to ask the question whether the current activities in the field of public diplomacy were sufficient

1 A. Williams, The U.S. Military and Public Diplomacy, [in:] Toward a New Public Diplomacy: Redirecting U.S. Foreign Policy, ed. Philip Seib, New York 2009, p. 217. 
and have achieved the desired results. Whether Afghanistan does not become a safe haven for terrorists again and the world will not witness another tragedy as $9 / 11$, depends largely on the victory in the battle for the "hearts and minds" of Afghans.

Public diplomacy was not created as a response to the attacks of September $11^{\text {th }}$. The United States have already used activities from its scope during the First and the Second World War. The goal was to reach audiences in Europe, win their "hearts and minds" and thus to influence the outcome of the wars. The further fate of American public diplomacy have been inextricably linked with the activities of the United States Information Agency (USIA), established in 1953 to combat Soviet propaganda and the spread of communism. With the dissolution of the USSR, its role was severely diminished, and with reduced funds, international broadcasting and exchange programs must have been scaled down. In 1999, USIA was abolished as part of post-Cold War reorganization, and its responsibilities were transferred to the Department of State (DOS). This obvious neglect of public diplomacy stemmed from the conviction that the danger has been eradicated. The events of September $11^{\text {th }}$ challenged the validity of this belief the hard way.

In the wake of the 9/11 attacks, an increasingly intense national debate has evolved on the role of the public diplomacy in the struggle against world terrorism and growing anti-Americanism, particularly in the Islamic world ${ }^{2}$. Although the participants in the discussion - members of Congress, public intellectuals, public affairs professionals - held different views on what mistakes have been made and how to overcome current difficulties, they all recognized its importance as a vital element of the national security.

Public diplomacy according to its professional practitioners is a program carried out by the government aimed at understanding and engaging with foreign publics, in order to serve American interests 3 . The primary responsibility for planning, funding and implementation of public diplomacy programs rests with the Department of State and the UnderSecretary of State for Public Diplomacy and Public Affairs. The responsibility of the Secretary of State is to make public diplomacy an integral component in the planning and execution of U.S. foreign policy and to coordinate the public diplomacy activities of the federal agencies, particularly Broadcasting Board of Governors and USAID. Also the Under Secretary is obliged to assist the USAID and BBG in presenting the policies of the United States ${ }^{4}$. In current US foreign

2 B. Ballow, Academic and Professional Exchanges with the Islamic World, [in:] Engaging the Arab o Islamic World through Public Diplomacy: A Report and Action Recommendations, (ed.) William A. Rugh, Washington 2004, p. 110.

3 W.A. Rugh, Repairing American Public Diplomacy, http://www.arabmediasociety.com/?article=709 (accessed 26.07.2014).

4 K.H. Nakamura, M.C. Weed, U.S public Diplomacy: Background and Current Issues, Congressional Research Service, December 18, 2009, p. 4. 
policy, public diplomacy continues to be part of civilian power, described by the US government as: "the combined force of civilian personnel across all federal agencies advancing America's core interests in the world", and as such, it includes the work of diplomats, but also of USAID and other (development) agencies working abroad 5 .

The mission of American public diplomacy led by the Department of State "is following: To support the achievement of U.S. foreign policy goals and objectives, advance national interests, and enhance national security by informing and influencing foreign publics and by expanding and strengthening the relationship between the people and government of the United States and citizens of the rest of the world"6.

To accomplish this mission, US international messages must be credible and truthful. There is no effective public diplomacy or even no public diplomacy at all, if it is based on lies. The consistency of the message is inevitable. Sometimes, one word used by a prominent politician may thwart years of public diplomacy officers' hard work, not to mention million of dollars squandered. After 9/11, the challenge to U.S. public diplomacy in Arab and Muslim world was to make it clear that the United States is not engaged in a war against Islam ${ }^{7}$. Although George W. Bush declared that America is not Muslims' enemy and that it respects Muslims' faith, he also called war on terrorism a "crusade" 8 . Such choice of words, in addition with incidents of U.S. troops burning Koran can only heat the atmosphere and give rise to accuse Americans of hidden agenda. There is the persistent belief among Afghans that counterterrorism is just an excuse used by the United States to assert control over Afghanistan in order to extract resources, particularly mineral wealth, and to prevent the expansion of countries like China and Pakistan influence in the region? To reverse this kind of thinking a lot has to be done.

It is undeniable that public diplomacy has its limits. As Mark Leonard puts it: "You can't imagine that soft power is going to convert Mohammed Atta or the Taliban". ${ }^{10}$ Although the terrorists will continue to despise America and its values,

5 J. Kamminga, Public Diplomacy In Afghanistan Beyond the 2014 Transition: Lessons from the United States and the Netherlands, "Discussion Papers In Diplomacy", no. 126, pp. 7-8.

6 Under Secretary for Public Diplomacy and Public Affairs, http://www.state.gov/r/ (accessed 26.07.2014).

7 H. Amin, The View from Egypt, [in:] Toward a New Public Diplomacy: Redirecting U.S. Foreign Policy, (ed.) Philip Seib, New York 2009, p. 113.

8 See Remarks by the President Upon Arrival, September 16, 2001, http://georgewbush-whitehouse. archives.gov/news/releases/2001/09/20010916-2.html (accessed 26.07.2014).

9 S. Miakhel, N. Coburn, Myths and Misconceptions in the Afghan Transition, "Peacebrief", April 9, 2012, http://www.usip.org/publications/myths-and-misconceptions-in-the-afghan-transition (accessed 4.08.2014).

10 M. Leonard, C. Smewing, Public Diplomacy and the Middle East, Foreign Policy Centre, 2003, p. 48. 
there is a need to reach out to those segments of Muslim populations that do not support Taliban insurgency but who still have mixed feelings about the U.S. ${ }^{11}$

The ability to craft the right messages for the right audiences is crucial and requires enormous effort, research and feedback, but it has to be coupled with a sure understanding of the cultures in which United States operates ${ }^{12}$. Meanwhile, according to Gallup Poll conducted in 2006, five years after 9/11, 57\% of Americans knew "not much" (43\%) or "nothing" (14\%) about beliefs and views of Muslims 13 . Moreover, significant majorities of young Americans are unable to identify strategically or politically important countries, such as Iraq or Afghanistan, on a map of the world ${ }^{14}$.

Summing up, the vast majority of Muslims holds unfavorable views of what America does, not what America stands for. As John Esposito describes it: "The cause of anti-Americanism is not who we are but what we do"15. The results of another polls conducted after 9/11, when every American asked "why do they hate us?", were unambiguous. Most Muslims appreciate American values, freedom, technical and educational excellence but oppose American foreign policy. Here enters public diplomacy. As emphasized by William A. Rugh, public diplomacy "cannot itself eliminate all criticism of US policies, but it can help to mitigate objections by explaining the US government's reasons for these policies" 16 . One of the most invaluable instruments of American public diplomacy to accomplish this task is international broadcasting.

\section{International broadcasting}

For many years media scene in Afghanistan was in disarray. Under the Taliban rule, there was only one government radio station allowed to operate, there were no independent media and most of media infrastructure was destroyed. The situation has changed significantly when U.S.-led coalition troops intervened to dismantle

${ }_{11}$ L.A. Curtis, America's Image Abroad: Room for Improvement, "Heritage Lectures", No. 1027, 31 May, 2007, http://www.heritage.org/research/lecture/americas-image-abroad-room-for-improvement, (accessed 14.06.2014).

12 Christopher Ross, Pillars of Public Diplomacy. Grappling with International Public Opinion, "Harvard International Review", Summer 2003;25, 2, p. 25.

${ }^{13}$ How citizens of the United States and predominantly Muslim Nations see each other, Gallup World Poll 2006, http://www.brookings.edu/ /media/events/2007/2/17islamic\%20world/20070217mogahed. pdf (accessed 23.08.2014).

14 U.S. Education Reform and National Security, Council on Foreign Relations, Independent Task Force Report No. 68, 2012, http://www.cfr.org/united-states/us-education-reform-national-security/p27618 (accessed 06.08.2014).

15 J.L. Esposito, The future of Islam, New York 2010, p. 196.

16 W.A. Rugh, Repairing..., op. cit. 
the Taliban regime. Nowadays there are more than 175 FM radio stations, 75 TV channels, news agencies, print publications and internet cafes in major cities ${ }^{17}$.

Afghans have a strong desire for news and information - vast majority wants to stay informed about current events in the country. They are also interested in international matters, but mostly to the extend they have impact on the situation in Afghanistan ${ }^{18}$. To obtain information most Afghans use radio (80\%), around half use cell phones $(57 \%)$ and television $(54 \%)^{19}$. While the media industry is flourishing (the numbers are impressive), it is still in the development stage. A major contribution to this development come from U.S. international broadcasting. It is based on two entities - Voices of America (VOA) and Radio Free Europe/Radio/Liberty (RFE/ RL). During the Taliban regime VOA broadcast on shortwave until 2006, when it turned to FM as Radio Ashna, which broadcasts 12 hours per day (7:00 p.m. to 7:00 a.m.). In addition to radio broadcasts, VOA produces also television program. TV Ashna broadcasts six days a week for one hour (30 minutes in Dari and 30 minutes in Pashto). VOA's branches feature news service and call-in shows. RFE/RL's Radio Azadi (local name for Radio Free Afghanistan) was reinstated in 2001 and since 2002 it broadcasts 12 hours per day (7:00 a.m. to 7:00 p.m.) forming a continuous block with Radio Ashna. Radio Azadi is the leading media outlet in Afghanistan, reaching more than $60 \%$ of the Afghan population ${ }^{20}$. Its popularity stems from solid news service, call-in shows and roundtables. "As a result, despite decades of violence, it has established a culture of debate and discussion among its listeners on major national and international issues" 21 .

The main goal of U.S. international broadcasting in Afghanistan is to increase the Afghan's people access to objective news and empower functioning of independent press. Another way to achieve these goals is supporting media industry development by providing funds. After defeating the Taliban regime, U.S. government agencies have spent hundreds of millions of dollars on Afghan media industry, thus the Unites States have become the biggest media investor in Afghanistan (USAID's funds for media development and journalists training alone totaled about 65 million dollars from 2002 to 2011)22. Among many projects supported with American money, the most recognizable and successful was investing in Moby Group.

\footnotetext{
17 P. Cary, An Explosion of News: The State of Media In Afghanistan, A Report to the Center for International Media Assistance, February 23, 2012, p. 4.

${ }^{18}$ Afghanistan media survey: report prepared for BBC Trust, p. 5, http://www.bbc.co.uk/bbctrust/assets/ files/pdf/review_report_research/ar2007_08/afghanistan_research.pdf (accessed 5.08.2014).

${ }^{19}$ Only 3\% of Afghans use the Internet, mostly because of high illiteracy rate and high cost of connectivity. Afghanistan in 2013: A Survey of the Afghan People, The Asia Foundation 2013, http:// asiafoundation.org/country/afghanistan/2013-poll.php (accessed 14.08.2014).

${ }^{20}$ RFE/RL's Radio Azadi, http://www.rferl.org/info/afghan/181/html (accessed 26.07.2014).

21 Ibidem.

22 P. Cary, An Explosion..., op. cit., p. 24.
} 
With initial seed money (2.7 million dollars) from the U.S. government, the company launched a radio network and by late 2010 owned Tolo TV (leads national TV viewership with $59 \%$ of audience share), Tolo News (the country's only 24 -hour satellite news channel), Arman FM Radio, a record company, ad agency, movie production company and four Internet cafes ${ }^{23}$. Generally speaking, all of these actions seem to bear fruit. According to research conducted by Altai Consulting the most trusted source of information in Afghanistan is the radio and television. Furthermore, more than $30 \%$ of respondents reported that they often discuss the issues raised in the media with relatives and friends and $80 \%$ said that media exert a strong influence on their opinions ${ }^{24}$.

At the same time, it should be stressed that extremists also use the media to spread their message. Public statements appear on television, radio and Internet. The Taliban put also great efforts into "conveying preaching and battle reports via DVDs, audio cassettes, shabnamah (night letters - pamphlets or leaflets usually containing threats) and traditional songs and poems". 25 They also take measures to soften their image, for example, by releasing a code-of-ethics manual with instructions not to recruit children and to avoid civilian casualties. ${ }^{26}$ Therefore important function of broadcasting activities, in addition to promoting freedom of the press and the free flow of information, is to counter the Taliban propaganda.

\section{Exchange programs}

Public diplomacy is not just broadcasting a message. Equally important are educational and professional exchange programs, as well as English teaching. They demonstrate America's long-term commitment and are powerful tools for reaching at-risk audience. As Walter Douglas concludes: "Messaging on the news of the day is important, but strategically employed exchanges and English-teaching offer powerful long-term results no matter what the short-term policy differences are" 27 .

The most recognizable and successful of the U.S.-sponsored exchange programs is the Fulbright Program. It is an international educational program (under the purview of the Department of State) that sends American students, scholars

\footnotetext{
${ }^{23}$ Afghanistan media boomed during war, but faces uncertain future as U.S. withdraws, http://www.huffingtonpost.com/2013/01/30/afghanistan-media-afghan-war_n_2574818.html (accessed 26.07.2014).

24 P. Cary, An Explosion..., op. cit., p. 38.

25 Taliban Propaganda: Winning the War of Words?, International Crisis Group, Asia Report $\mathrm{N}^{\circ} 158$, 24 July 2008, http://www.crisisgroup.org/en/regions/asia/south-asia/afghanistan/158-talibanpropaganda-winning-the-war-of-words.aspx (accessed 25.07.2014).

26 J. Kamminga, Public Diplomacy..., op. cit., p. 11.

27 W. Douglas, J. Neal, Engaging the Muslim World. Public Diplomacy after 9/11 in the Arab Middle East, Afghanistan, and Pakistan, Center for Strategic and International Studies, November 2013, p. vi.
} 
and professionals overseas and brings foreign students, scholars and professionals to the United States to study, teach and conduct research for a certain time ${ }^{28}$. The goal of this "flagship" exchange program is to "enable individuals to learn from and interact with the world in a way that fosters mutual understanding and forges crucial cross-cultural relationships in an increasingly interdependent environment" 29 . It operates in more than 155 countries, also in Afghanistan, and awards over 8,000 grants annually. The Fulbright Program was present in Afghanistan since 1952, but was suspended in 1979, after the Soviet invasion, and in consequence absent for almost quarter of a century. The U.S Department of State reinstated it in 2003 to rebuild academic ties with war-torn Afghanistan ${ }^{30}$. Currently, there are couple of Fulbright programs available for Afghans:

- Fulbright Foreign Students Doctoral Scholarships - funds 5 years of doctoral study in the U.S., pursue a doctoral (PhD) degree in Agriculture, Communications, Economics, Education, Engineering, Math, Science or Technology.

- Fulbright Foreign Students Graduate Scholarships - funds 2 years of graduate study in the U.S., pursue a graduate degree in any discipline.

- Hubert H. Humphrey Fellowship - 10-month non-degree program for mid-career professionals, gives opportunity for both professional training and academic coursework.

- Foreign Language Teaching Assistantship - nine-month, non-degree program, gives opportunity for both teaching and studying at U.S. colleges/universities; provides teachers of English, Dari and Pashtu with the opportunity to refine their skills; strengthens eligibility for graduate studies at international institutions and in the Fulbright programs ${ }^{31}$.

The most recent program devoted to Afghans, initiated in January 2011, is the Afghan Junior Faculty Development Program. It is a 10 week intensive professional training program at a U.S. university, the purpose of which is identified as "to enhance and

28 Currently, there are no Fulbright Program opportunities for US citizens in Afghanistan, mainly due to security reasons. Prachi Naik, An Examination of the Fulbright Program. International Educational Exchange from a National Security Perspective, August 2012, p. 7, http://americansecurityproject. org/ASP\%20Reports/Ref\%200078\%20-\%20An\%20Examination\%20of\%20the\%20Fulbright\%20 Program.pdf (accessed 17.08.2014).

29 Ibidem, p. 4.

30 The Fulbright Program in Afghanistan has grown significantly, from 20 students in 2003-2004 to 47 in 2011 and 55 in 2012, see J. WILLIAM FULBRIGHT FOREIGN SCHOLARSHIP BOARD, Annual Report 2011-2012, http://eca.state.gov/files/bureau/2011-2012_ffsb_annual_report.pdf (accessed 26.07.2014).

31 Since 2009, there are no longer undergrad scholarships available. For five key scholarships opportunities offered by U.S Embassy in Afghanistan see: http://kabul.usembassy.gov/educational_exchange. html (accessed 26.07.2014). 
broaden the professional skill sets of Afghan junior faculty in various fields of study; to provide insight into the American system of higher education; and to increase mutual understanding between the people of the United States and the people of Afghanistan"32.

The U.S. government recognizes also the importance of English language education. The purpose of such programs in countries like Afghanistan is to make the study of English more accessible to students and teachers. These programs give participants means to improve their language skills, which increases the likelihood of getting into an exchange program in the future. Investing in teachers training, on the other hand, broadens the base of professionals, who can then pass on their knowledge to Afghan students. This is also the opportunity for Afghan people to improve their employment outlook, but the most important purpose is "to expose youth to a wider world, develop critical thinking, and provide them with prospects in life that may prevent them from turning to violence" 33 .

The most significant of the available English teaching programs is English Access Microscholarship Program, which provides a foundation of English language skills to non-elite, 14-18 year old students living in underserved neighborhoods through afterschool classes and intensive summer learning activities. Through participation in the program, students should "gain an appreciation for American culture and democratic values, increase their ability to participate successfully in the socioeconomic development of their countries, and gain the ability to compete for and participate in future U.S. exchange and study programs" 34 . So far the numbers are promising - as reported by the U.S. embassy in Kabul, over 3,000 Afghan students have entered the program since its inception in 2004. The effectiveness of the Access Program is high. The main findings of the program's evaluation carried out by the Bureau of Educational and Cultural Affairs are:

- The Access Program changed students' attitudes towards the American people and the U.S. administration - 87,5\% report a more favorable or much more favorable view of American people and 54,3\% report a more favorable or much more favorable view of the U.S. government.

- The overwhelming majority of Access students assessed the acquired language skills as good or excellent.

- Over $85 \%$ of evaluated students reported sharing knowledge from the Access classes with parents, siblings and peers ${ }^{35}$.

32 See "Junior Faculty Development Program", http://kabul.usembassy.gov/junior_faculty.html (accessed 26.07.2014).

33 W. Douglas, J. Neal, Engaging..., op. cit., pp. 18-19.

${ }^{34}$ English Language Development Programs and Resources offered by the Public Affairs Section, http:// kabul.usembassy.gov/english_language.html (accessed 26.07.2014).

${ }^{35}$ For detailed data and methodology see https://eca.state.gov/files/bureau/english-access-final-report_reformattedx.pdf (accessed 26.07.2014). 
An example of a program dedicated to teachers is the E-Teacher Scholarship Program. It offers English teaching professionals in Afghanistan (among other countries) the opportunity to take online, graduate level classes through the University of Maryland, Baltimore County and the University of Oregon. Proposed courses explore major areas of the academic specialty of Teaching English as a Foreign Language (TEFL) - one of them is Teaching English to Young Learners (TEYL) ${ }^{36}$.

Another extremely important educational initiative is establishing in 2006 the American University of Afghanistan in Kabul - the outcome of cooperation of the United States government with Afghan Ministry of Higher Education, Afghan business leaders and private donors. Currently, it is the only private, non-profit, nonpartisan and co-educational university in Afghanistan, offering degrees in business administration, information technology and computer science, political science, and public administration. AUAF is gaining popularity, as evidenced by the fact that it has grown from 50 enrolled students in 2006 to more than 1,700 full and part-time students in 2014. ${ }^{37}$ University expands its operations through new initiatives such as Undergraduate Scholars Program for alumni of U.S. government-sponsored programs. It is worth mentioning that AUAF itself produced 29 Fulbright Scholars.

The fact that United States take action in the field of public diplomacy in Afghanistan (educational programs specifically) does not mean that these measures are effective. However, it is important to realize that "the investment in people takes time to pay dividends" 38 . It is not enough to simply count how many students participated in exchange programs. These programs may have greatest effect years later, when the former students have become government officials. Nevertheless, some kind of evaluation is necessary. Based on data from surveys conducted by Zogby International and Chicago Council on Foreign Relations shortly after the 9/11, it can be argued that people who have closer contacts and better information about the US (for example by following international TV channels) are less likely to hold negative views of the country ${ }^{39}$. Educational and cultural programs are annually assessed by the Department of State, which collects data directly from program participants. In 2012, almost all respondents (97\%) reported an increase or positive change in their understanding of the United States (political and economic institutions, norms and values). Although, there are some variations from year to year (figure 1), the general trend is that each year participants' perceptions of the United States are positively impacted by their experiences ${ }^{40}$.

\footnotetext{
36 Ibidem.

37 See http://auaf.edu.af/about/ (accessed 26.07.2014).

38 Walter Douglas, Jeanne Neal, Engaging..., op. cit., p. 12.

39 G. Chiozza, Anti-Americanism and the American World Order, Baltimore 2009, p. 112.

40 Department of State-USAID Joint Summary of Performance and Financial Information for Fiscal Year 2012, http://www.usaid.gov/sites/default/files/documents/1868/StateUSAIDJoint2012SummaryRe-
} 
Similarly, $71 \%$ of the respondents reported a more favorable view of U.S. government and 85\% expressed more favorable view of American people. The conclusion of the report is clear - "results show the effectiveness of educational and cultural exchange programs in positively and substantively reshaping understanding of, and attitudes toward, the United States"41. As Barry Ballow puts it: "The strongest admirers of the United States, and those who generally understand us best, are typically those who spent months or years in the United States as students, teachers, or research scholars. These individuals, selected for exchange programs because of their intellectual and leadership qualities, have usually established relationships with American colleagues, institutions, and communities" 42 . Giacomo Chiozza draws similar conclusions: "The more two societies interact and have contacts at the economic and cultural level, the more sense of "fellow-feeling" between individuals in those societies is likely to emerge. The more US trades, invests, and grants visas for a country's students, the more that countries' residents will be prone to express positive views of the US" 43 .

It can be argued that educational and cultural exchange programs help to reduce anti-American attitudes and thus, contribute to increase the security of the United States. At the same time, it should be emphasized that these programs are not available to everybody due to a whole list of requirements (first of all concerning English skills) on the one hand, and safety concerns on the other, as there is a certain risk in being a recipient of a U.S.-sponsored scholarship.

\section{Development assistance}

The tool, which at least in theory, can be applied to the whole society is development and humanitarian assistance. As it was mentioned at the beginning, nowadays American public diplomacy is an interagency effort. Although the Department of State is recognized as a leading organization to conduct public diplomacy, the mission of USAID is also tied to achieving its objectives .One of them is to turn Muslim populations away from supporting al Qaeda and other violent organizations. To do so, it is necessary to support the development of the state in terms of political, economic and social improvement. In all these areas, USAID is actively working to enhance Afghan opportunities so that they have alternatives to insurgency. A list of USAID's accomplishments is long and impressive - here are a few of those concerning economy growth - USAID:

port_030513.pdf, (accessed 05.08.2014).

41 Ibidem.

42 B. Ballow, Academic..., op. cit., p. 111.

43 G. Chiozza, Anti-Americanism..., op. cit., p. 140. 
- "helped increase revenue collection, improve the legal and regulatory framework for private sector investment, grow small and medium sized businesses, implement regional trade agreements, and strengthen the government's capacity to manage the economy,

- created 490,000 new jobs, which can be directly attributed to USAID programs,

- assisted in the licensing of 17 licensed commercial banks with $\$ 840$ million in outstanding loans and $\$ 3.5$ billion in deposits,

- facilitated more than 830,000 micro-finance loans to Afghan women during the last eight years and developed more than 175,000 micro- and smallbusinesses,

- launched 50 public-private partnerships leveraging more than \$95 million from private sector-partners in insurance, communications/media, apparel, information technology, natural resource extraction, and food processing" 44 .

It is essential to realize that although security issues are important and widely recognized, a concern of the average Afghan is rather related to his economic situation. According to Gallup Poll (October 2009), the most frequent responses to an open-ended question about the single most important problem Afghan families are facing were: bad economy in local city or region (21\%), unemployment (20\%), high costs of goods/personal financial problems (15\%), and lack of security $(15 \%)^{45}$. This trend is also true today. The results of the Asia Foundation's Survey of Afghan People (2013) are very similar. At the local level, Afghan people are most concerned about: unemployment (27\%), electricity (24\%), roads (19\%), drinking water (19\%), insecurity (14\%), healthcare (13\%) and education $(11 \%)^{46}$. Yet, still $76 \%$ of respondents reported that their household economic situation is better now than under the Taliban rule ${ }^{47}$. To sustain this trend, public diplomacy efforts should focus on further development assistance, which should convince Afghans why it is in their interest to align themselves with the West. USAID and Department of State spent high amounts of money to make it happen, providing support in many areas (figure 1).

44 USAID’s Major Accomplishments Since 2001, http://kabul.usembassy.gov/usaidd50.html (accessed 21.07.2014).

45 See Measuring the State of Muslim-West Relations: Assessing the "New Beginning", November 2010, http://www.gallup.com/poll/144959/measuring-state-muslim-west-relations.aspx (accessed 12.08.2014).

46 Afghanistan in 2013: A Survey..., op. cit.

47 Ibidem. 


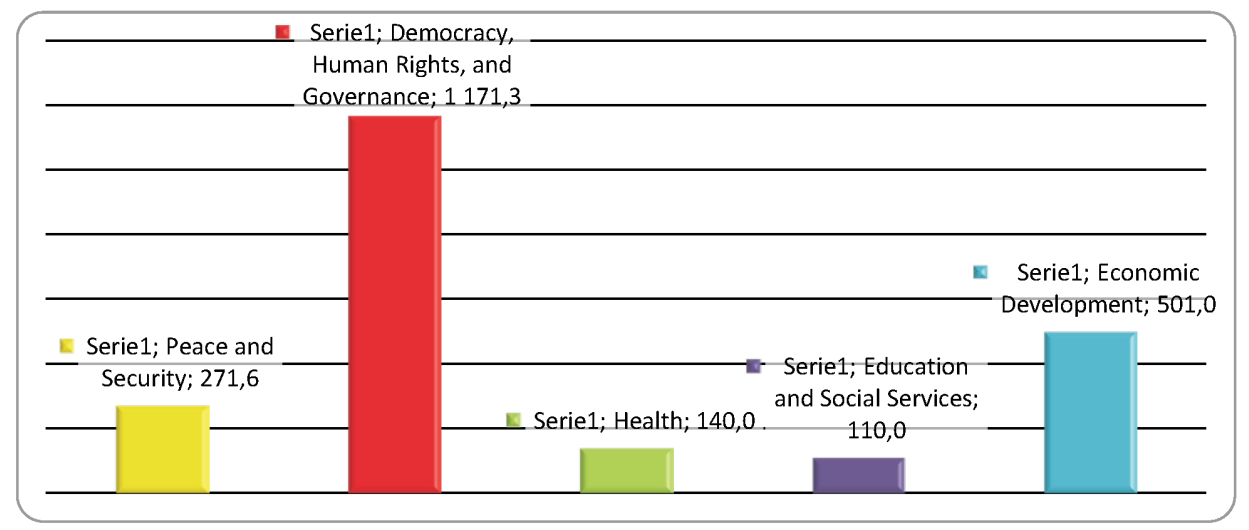

Figure 1. Category Appropriation Details, FY 2014Afghanistan - DOS and USAID, Million \$ Source: www.foreignassistance.gov

Past USAID activities and cooperation with the DOS should be highly evaluated, but still there is a lot to be done. Expenditure on public diplomacy (including development assistance) are incomparably lower than spending on military mission, and further downward trend is noticeable (figure 2).

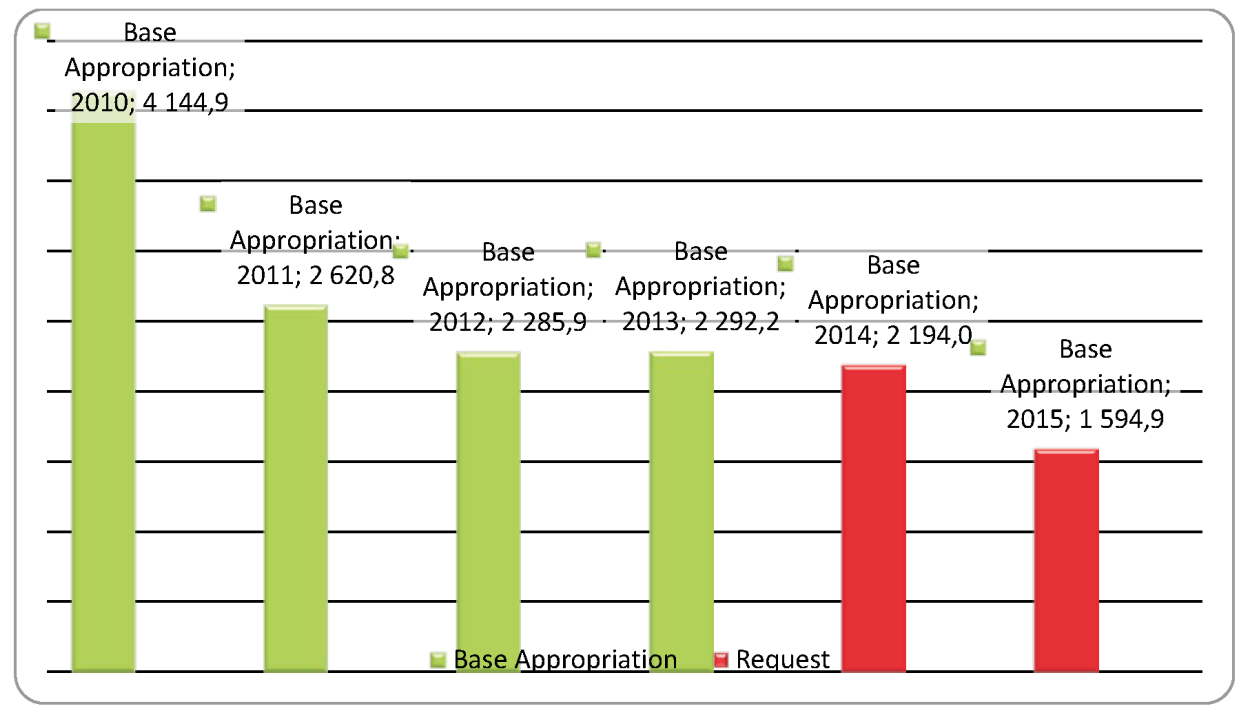

Figure 2. Foreign Assistance Levels by Fiscal Year Afghanistan - DOS and USAID, Million \$ Source: www.foreignassistance.gov

Notwithstanding these alarming figures, efficient communication and operational cooperation between the Department of State and USAID should be developed, 
with USAID playing "prominent role in the planning and implementation of projects aimed at reaching all levels of society" as "USAID officials in country who are working closely with the development community often have a better understanding of the needs of the grassroots level of society" 48 . It is essential to realize that democratic and economic reforms will be jeopardized without international help ${ }^{49}$. As a new American intelligence assessment on the Afghan war predicts, the gains the United States and its allies have made during the past three years are likely to have been significantly eroded by 2017, especially if the Bilateral Security Agreement is not signed. Without BSA Afghanistan will not receive billions of dollars in economic and military assistance that were supposed to be spent in Afghanistan over the coming years ${ }^{50}$. Many believe that country's ability to cope with the Taliban will vanish soon after the international forces withdraw.

What is worth noting is the fact that, contrary to appearances, a lot of Afghans support the presence of international forces in their country and do not necessarily wait for the Taliban to regain power. In 2006, according to the poll conducted by Charney Research for ABC NEWS/BBC World Service, three in four Afghans appreciated the NATO troops' presence and $60 \%$ of the respondents wanted them to stay in Afghanistan until security is restored ${ }^{51}$. The survey conducted four years later by $\mathrm{ABC} / \mathrm{BBC} / \mathrm{ARD}$ found that $62 \%$ of Afghans support U.S. military presence, which is much higher than number of Americans who back the mission ${ }^{52}$. In the Asia Foundation survey (2013) Afghans asked about country's biggest problems, identified insecurity (30\%), corruption (26\%), unemployment (25\%), and the economy (10\%) as the top four concerns, while presence of foreign troops (4\%) took fifteenth place ${ }^{53}$.

48 L.A. Curtis, America's Image..., op. cit.

${ }^{49}$ According to the World Bank, 97\% of the country's domestic product is tied to the presence of ISAF and the donor community. See Jason Lyall, Afghanistan's lost decade, "Foreign Affairs", December 15, 2011, http://www.foreignaffairs.com/articles/136787/jason-lyall/afghanistans-lost-decade (accessed 6.08.2014).

${ }^{50}$ Ernesto Londoño, Karen DeYoung, Greg Miller, Afghanistan gains will be lost quickly after drawdown, U.S. intelligence estimate warns, http://www.washingtonpost.com/world/national-security/ afghanistan-gains-will-be-lost-quickly-after-drawdown-us-intelligence-estimate-warns/2013/12/28/ ac609f90-6f32-11e3-aecc-85cb037b7236_story.html (accessed 26.07.2014).

${ }^{51}$ P.H. Gordon, Winning the right war: the path to security for America and the world, New York 2007, p. 132.

52 In November 2001 fewer than 1 in 10 Americans said that U.S. intervention in Afghanistan was a mistake, while according to Gallup's World Affairs survey conducted in February $2014-49 \%$ of Americans say that it was a mistake. See Frank Newport, More Americans Now View Afghanistan War as a Mistake, http://www.gallup.com/poll/167471/americans-view-afghanistan-war-mistake. aspx?version=print. (accessed 26.07.2014).

53 Afghanistan in 2013: A Survey..., op. cit. 


\section{Conclusions}

As American troops prepare to withdraw by the end of the year, the question arises about the future of Afghanistan and future public diplomacy efforts toward it. Although it is undeniable that Afghanistan has undergone significant changes, further progress will depend on the attitudes and actions of Afghan government, society and the international community. At the moment, Afghans are confused and unsure of tomorrow as the results of presidential elections are uncertain, security pact is unsigned and it is still unknown whether or not American engagement in Afghanistan will be sustained beyond 2014. Now, more than ever, the United States must overcome the 'trust deficit' it faces in Afghanistan, where many believe that it is not a reliable long-term partner, and match rhetoric with actions ${ }^{54}$. Afghanistan should not fall off the radar of the global community again, as it happened after the Cold War. Accordingly, public diplomacy efforts should be intensified. However, with transition decade ahead, there is a need to re-think the conduct of public diplomacy. It is vital to look for new angles as well as care for the basics. Among many recommendations concerning American public diplomacy in Afghanistan, these are primary - the U.S. government should:

- recognize public diplomacy as a vital element of national security strategy,

- reach out to young Afghans by, inter alia, expanding education and exchange programs and the use of social media in spreading the message,

- put greater emphasis on coordination of public diplomacy and strategic communications activities of all U.S government agencies (especially Department of State and USAID),

- elevate the mission of USAID and recognize the role of development assistance in achieving national security objectives,

- provide adequate funding and political backing for public diplomacy efforts in Afghanistan beyond 2014.

Two decades of conflict - during which Afghanistan experienced Soviet occupation, jihad, civil war, Taliban rule, and Operation Enduring Freedom - have left the country a wasteland ${ }^{55}$. Never well developed, the country is at a crossroads. Contrary to the expectations of frustrated Afghans, recovery will not happen overnight - there are no quick fixes and shortcuts to progress. Similarly, public diplomacy alone will not defeat terrorism. But the breeding grounds for terrorism will be far less fertile if a public diplomacy strategy encompasses policy, perceptions, demographics, and

\footnotetext{
${ }^{54}$ White Paper of the Interagency Policy Group's Report on U.S. Policy toward Afghanistan and Pakistan, p. 2, http://www.whitehouse.gov/assets/documents/Afghanistan-Pakistan_White_Paper.pdf(accessed 14.08.2014).

55 J. Lyall, Afghanistan's lost..., op. cit.
} 
education ${ }^{56}$. As Esposito argues, the threat to the West will not come from civilization differences but from the political and socioeconomic reality that breeds radicalism ${ }^{57}$. Without meaningful reforms and international assistance, the world may witness another round of civil war after 2014. Both counterinsurgency and changing "hearts and minds" will require high-level attention on Afghanistan sustained over years to come.

\section{REFERENCES:}

1. Afghanistan in 2013: A Survey of the Afghan People, The Asia Foundation 2013, http:// asiafoundation.org/country/afghanistan/2013-poll.php (accessed 14.08.2014).

2. Afghanistan media boomed during war, but faces uncertain future as U.S. withdraws, http:// www.huffingtonpost.com/2013/01/30/afghanistan-media-afghan-war_n_2574818.html (accessed 26.07.2014).

3. Afghanistan media survey: report prepared for BBC Trust, http://www.bbc.co.uk/bbctrust/ assets/files/pdf/review_report_research/ar2007_08/afghanistan_research.pdf (accessed 5.08.2014).

4. H. Amin, The View from Egypt, [in:] Toward a New Public Diplomacy: Redirecting U.S. Foreign Policy, (ed.) P. Seib, New York 2009.

5. B. BALlow, Academic and Professional Exchanges with the Islamic World, [in:] Engaging the Arab \& Islamic World through Public Diplomacy: A Report and Action Recommendations, (ed.) W.A. Rugh, Washington 2004.

6. P. CARY, An Explosion of News: The State of Media In Afghanistan, A Report to the Center for International Media Assistance, February 23, 2012.

7. G. ChiozzA, Anti-Americanism and the American World Order, Baltimore 2009.

8. L.A. CurTis, America's Image Abroad: Room for Improvement, "Heritage Lectures", No. 1027, 31 May, 2007, http://www.heritage.org/research/lecture/americas-image-abroadroom-for-improvement (accessed 14.06.2014).

9. Department of State-USAID Joint Summary of Performance and Financial Information for Fiscal Year 2012, http://www.usaid.gov/sites/default/files/documents/1868/StateUSAIDJoint2012SummaryReport_030513.pdf (accessed 5.08.2014).

10. W. Douglas, J. Neal, Engaging the Muslim World. Public Diplomacy after 9/11 in the Arab Middle East, Afghanistan, and Pakistan, Center for Strategic and International Studies, November 2013.

11. English Language Development Programs and Resources offered by the Public Affairs Section, http://kabul.usembassy.gov/english_language.html (accessed 26.07.2014).

12. J.L. Esposito, The future of Islam, New York 2010.

13. P.H. GoRDon, Winning the right war: the path to security for America and the world, New York 2007.

56 B. Fulton, The Uses of Modern Technology in Public Diplomacy, [in:] Engaging..., op. cit., p. 33.

57 J.L. Esposito, The future..., op. cit., p. 196. 
14. How citizens of the United States and predominantly Muslim Nations see each other, Gallup World Poll 2006, http://www.brookings.edu/ /media/events/2007/2/17islamic\%20 world/20070217mogahed.pdf (accessed 23.08.2014).

15. J. William Fulbright Foreign Scholarship Board, Annual Report 2011-2012, http://eca. state.gov/files/bureau/2011-2012_ffsb_annual_report.pdf (accessed 26.07.2014).

16. Junior Faculty Development Program, http://kabul.usembassy.gov/junior_faculty.html (accessed 26.07.2014).

17. J. Kamminga, Public Diplomacy In Afghanistan Beyond the 2014 Transition: Lessons from the United States and the Netherlands, "Discussion Papers In Diplomacy", no. 126.

18. M. Leonard, C. Smewing, Public Diplomacy and the Middle East, Foreign Policy Centre, 2003.

19. E. Londono, K. Deyoung, G. Miller, Afghanistan gains will be lost quickly after drawdown, U.S. intelligence estimate warns, http://www.washingtonpost.com/world/ national-security/afghanistan-gains-will-be-lost-quickly-after-drawdown-us-intelligence-estimate-warns/2013/12/28/ac609f90-6f32-11e3-aecc-85cb037b7236_story.html (accessed 26.07.2014).

20. J. Lyall, Afghanistan's lost decade, "Foreign Affairs", December 15, 2011, http://www. foreignaffairs.com/articles/136787/jason-lyall/afghanistans-lost-decade, (accessed 6.08.2014).

21. Measuring the State of Muslim-West Relations: Assessing the "New Beginning", November 2010, http://www.gallup.com/poll/144959/measuring-state-muslim-west-relations.aspx (accessed 12.08.2014).

22. S. Miakhel, N. Coburn, Myths and Misconceptions in the Afghan Transition, "Peacebrief”, April 9, 2012, http://www.usip.org/publications/myths-and-misconceptionsin-the-afghan-transition (accessed 4.08.2014).

23. K.H. Nakamura, M.C. Weed, U.S public Diplomacy: Background and Current Issues, Congressional Research Service, December 18, 2009.

24. P. NAIK, An Examination of the Fulbright Program. International Educational Exchange from a National Security Perspective, August 2012, http://americansecurityproject. org/ASP\%20Reports/Ref\%200078\%20\%20An\%20Examination\%20of\%20the\%20Fulbright\%20Program.pdf (accessed 17.08.2014).

25. F. Newport, More Americans Now View Afghanistan War as a Mistake, http://www. gallup.com/poll/167471/americans-view-afghanistan-war-mistake.aspx?version=print (accessed 26.07.2014).

26. Remarks by the President Upon Arrival, September 16, 2001, http://georgewbush-whitehouse.archives.gov/news/releases/2001/09/20010916-2.html (accessed 26.07.2014).

27. RFE/RL's Radio Azadi, http://www.rferl.org/info/afghan/181/html (accessed 26.07.2014).

28. C. Ross, Pillars of Public Diplomacy. Grappling with International Public Opinion, "Harvard International Review", Summer 2003;25, 2.

29. W.A. Rugh, Repairing American Public Diplomacy, http://www.arabmediasociety. com/?article $=709$ (accessed 26.07.2014). 
30. Taliban Propaganda: Winning the War of Words?, International Crisis Group, Asia Report N¹58, 24 July 2008, http://www.crisisgroup.org/en/regions/asia/south-asia/ afghanistan/158-taliban-propaganda-winning-the-war-of-words.aspx (accessed 25.07.2014).

31. Under Secretary for Public Diplomacy and Public Affairs, http://www.state.gov/r/, (accessed 26.07.2014).

32. USAID's Major Accomplishments Since 2001, http://kabul.usembassy.gov/usaidd50.html (accessed 21.07.2014).

33. U.S. Education Reform and National Security, Council on Foreign Relations, Independent Task Force Report No. 68, 2012, http://www.cfr.org/united-states/us-education-reformnational-security/p27618 (accessed 6.08.2014).

34. White Paper of the Interagency Policy Group's Report on U.S. Policy toward Afghanistan and Pakistan, http://www.whitehouse.gov/assets/documents/Afghanistan-Pakistan White_Paper.pdf

35. A. Williams, The U.S. Military and Public Diplomacy, [in:] Toward a New Public Diplomacy: Redirecting U.S. Foreign Policy, (ed.) P. Seib, New York 2009.

36. http://auaf.edu.af/about/ (accessed 26.07.2014).

37. https://eca.state.gov/files/bureau/english-access-final-report_reformattedx.pdf, (accessed 26.07.2014).

38. http://kabul.usembassy.gov/educational_exchange.html (accessed 26.07.2014).

\section{DYPLOMACJA PUBLICZNA STANÓW ZJEDNOCZONYCH AMERYKI W AFGANISTANIE}

Streszczenie. Stanom Zjednoczonym nie udało się zapobiec atakom terrorystycznym 11 września pomimo statusu supermocarstwa oraz ogromnego potencjału. Zdecydowana odpowiedź na ataki - w postaci interwencji w Afganistanie i Iraku - nie zapewniła Amerykanom poczucia bezpieczeństwa. Co więcej, działania te przyczyniły się do utraty przez Stany Zjednoczone popularności i wiarygodności na całym świecie, a w szczególności wśród społeczeństw muzułmańskich. W artykule poddano analizie działania USA z zakresu dyplomacji publicznej w Afganistanie i ich uwarunkowania, dokonano przeglądu instrumentów używanych do wygrania „serc i umysłów” Afgańczyków oraz przedstawiono wnioski i rekomendacje dotyczące prowadzenia dyplomacji publicznej w Afganistanie po 2014 roku. Słowa kluczowe: dyplomacja publiczna, Afganistan, Irak, konflikt, rozwiązywanie konfliktów, polityka bezpieczeństwa. 